University of Nebraska - Lincoln

DigitalCommons@University of Nebraska - Lincoln

Biological Systems Engineering: Papers and

Publications

Biological Systems Engineering

2020

\title{
Teacher Level Factors and Student Achievement in a Cyber- Enabled Engineering Education Professional Development Program
}

\author{
Wei Zakharov \\ Purdue University, wzakharov@purdue.edu \\ Johannes Strobel \\ University of Missouri, Columbia, strobelj@missouri.edu \\ Heidi A. Diefes-Dux \\ University of Nebraska-Lincoln, heidi.diefes-dux@unl.edu
}

Follow this and additional works at: https://digitalcommons.unl.edu/biosysengfacpub

Part of the Bioresource and Agricultural Engineering Commons, Environmental Engineering Commons, and the Other Civil and Environmental Engineering Commons

Zakharov, Wei; Strobel, Johannes; and Diefes-Dux, Heidi A., "Teacher Level Factors and Student Achievement in a Cyber-Enabled Engineering Education Professional Development Program" (2020). Biological Systems Engineering: Papers and Publications. 726.

https://digitalcommons.unl.edu/biosysengfacpub/726

This Article is brought to you for free and open access by the Biological Systems Engineering at DigitalCommons@University of Nebraska - Lincoln. It has been accepted for inclusion in Biological Systems Engineering: Papers and Publications by an authorized administrator of DigitalCommons@University of Nebraska Lincoln. 


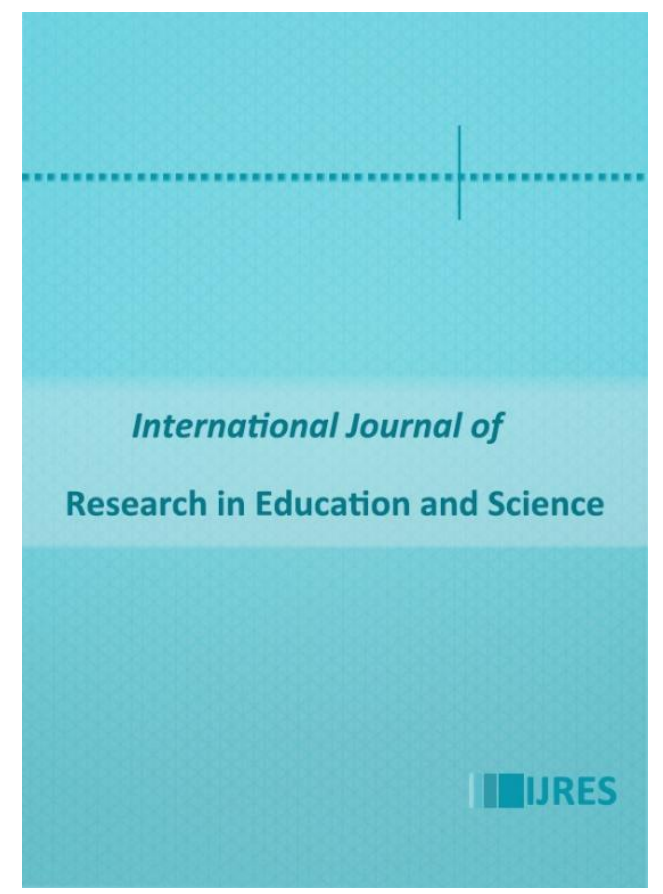

\title{
Intemational Jounal of Research in Education and Science (IJRES)
}

www.ijres.net

\section{Teacher Level Factors and Student Achievement in a Cyber-Enabled Engineering Education Professional Development Program}

\author{
Wei Zakharov ${ }^{1}$, Johannes Strobel ${ }^{2}$, Heidi A. Diefes-Dux ${ }^{3}$ \\ ${ }^{1}$ Purdue University \\ ${ }^{2}$ University of Missouri, Columbia \\ ${ }^{3}$ University of Nebraska-Lincoln
}

ISSN: $2148-9955$

To cite this article:

Zakharov, W., Strobel, J., \& Diefes-Dux, H.A. (2020). Teacher level factors and student achievement in a cyber-enabled engineering education professional development program. International Journal of Research in Education and Science (IJRES), 6(1), 48-60. 


\title{
Teacher Level Factors and Student Achievement in a Cyber-Enabled Engineering Education Professional Development Program
}

\author{
Wei Zakharov, Johannes Strobel, Heidi A. Diefes-Dux
}

\begin{tabular}{|c|c|}
\hline Article Info & Abstract \\
\hline Article History & $\begin{array}{l}\text { This study investigates the impact of an elementary engineering education } \\
\text { teacher professional development program on student learning. The results }\end{array}$ \\
\hline $\begin{array}{l}\text { Received: } \\
\text { 30 October } 2018\end{array}$ & $\begin{array}{l}\text { show a significant increase in students' knowledge in science from pre- to } \\
\text { post-test as well as in engineering design from grade two to grade four. }\end{array}$ \\
\hline $\begin{array}{l}\text { Accepted: } \\
19 \text { March } 2019\end{array}$ & $\begin{array}{l}\text { Further, the study uses multilevel modeling to quantitatively analyze the } \\
\text { impact of differences among teachers on the engineering design achievement } \\
\text { of their students. Different predictive relationships between demographic and }\end{array}$ \\
\hline Keywords & $\begin{array}{l}\text { social capital factors at the teacher level and student achievement are } \\
\text { identified and implications for educational policymaking and practices are }\end{array}$ \\
\hline $\begin{array}{l}\text { Elementary engineering } \\
\text { education } \\
\text { Teacher professional } \\
\text { development } \\
\text { Teacher social canital }\end{array}$ & discussed. \\
\hline
\end{tabular}

\section{Introduction}

The engineering education community has called for more engineering emphasis in the K-12 classroom since the landmark National Academy of Engineering (NAE) report Changing the Conversation was published in 2008. The NAE (2008) report revealed waning student interest in engineering, poor educational preparedness, a lack of diverse representation in the field, and low persistence of U.S. engineering students. In the review of the state of P-12 engineering education, Carr, Bennett \& Strobel (2012) discussed the initial surge in development of individual state standards that emphasize the integration of engineering thinking and skills development with traditional elementary curricular content (i.e., language arts, math and science). In 2014, the Next Generation Science Standards (2014) listed core practices and concepts from engineering alongside those for science, broadening the role of engineering design and elevating it to the same level as scientific inquiry.

Research has shown a possible remedy for the lack of K-12 engineering education could begin in elementary schools, where the interest and drive to participate in engineering must be fostered at an early age (Duncan, Oware, Cox, \& Diefes-Dux, 2007). However, Brophy, Klein, Portsmore, and Rogers (2008) point out that many P-8 teachers' backgrounds do not include engineering and list teachers' readiness and professional development as the first major challenge to further elementary engineering education. There is a clear need for research and discovery-based educational programs to introduce elementary teachers and students to engineering.

\section{INSPIRE Teacher Professional Development Program}

The Research Institute for Pre-college Engineering (INSPIRE) at a large Midwest research university provided in-service elementary teachers from one large school district in the south-central United States with professional development opportunities in engineering education ("DRK-12 Quality Cyber-Enabled, Engineering Education Professional Development to Support Teacher Change and Student Achievement" project funded by the National Science Foundation). The program aimed to integrate engineering and engineering thinking into elementary education. Unlike short-term workshops, the program provided multiple years, ongoing learning, mentoring, and networking opportunities for the development of teachers' pedagogical knowledge and content skills in engineering education (Barab, Kling, \& Gray, 2004; Liu , Carr, \& Strobel, 2009 \& 2012). Diefes-Dux (2014 \&2015) introduced the INSPIRE teacher professional development program and reported an overview.

The INSPIRE teacher professional development program was innovative in terms of 1) the introduction of a new content area, which was mostly unfamiliar to teachers (e.g. engineering), 2) learning community 
development (both face-to-face and through electronically-mediated means) in which teachers discussed and collaborated on teaching and learning engineering-integrated curriculum (Liu, Carr, \& Strobel, 2009; Strobel \& Liu, 2010), and 3) new pedagogical approaches that integrated model-electing activities (MEAs) (Zawojewski, Diefes-Dux, \& Bowman, 2008) and "Engineering is Elementary (EiE)" units (http://www.eie.org).

Teachers of grades 2 to 4 in the school district applied for this school-based professional development program. The first cohort attended a week-long summer academy in 2008. The next summer they returned for a three-day academy. Likewise, in the summer of 2009, the second cohort attended a week-long academy and returned for a three-day academy in the summer of 2010. The program had four cohorts in total from this single school district. These teachers receive engineering teacher professional development in cohorts and, upon returning to their classrooms in the subsequent academic year, taught the engineering lessons/curriculum in their classrooms.

\section{Underlying Theoretical Perspectives}

From Vygotsky's social constructivist perspective, the socio-cultural context influences the thinking and creation of meaning. The process of formulating meaning consists of negotiation among participants through dialogues or conversations. The opportunity to interact with other learners in sharing, constructing and negotiating meaning leads to knowledge construction. Within a constructivist model, Jonassen(2000) points out that learning is based on constructing meaning from experience and interpreting the world largely through the social processes.

Communities of Practice are viewed as emergent, self-reproducing and evolving entities, which are distinct from, and frequently extend beyond, formal organizational structures with their own organizing structures, norms of behavior communication channels, and history (Wenger, 1998). According to Schlager and Fusco (2004), members often come from multiple organizations drawn to one another for both social and professional reasons. Newcomers gain access to the community's professional knowledge tools and social norms through peripheral participation in authentic activities with other members.

Forming a community in cyber-enabled teacher professional development is essential (Wenger, 1998). According to Wilson and Ryder (1996), "groups become communities when they interact with each other and stay together long enough to form a set of habits and conventions and when they come to depend upon each other for the accomplishment of certain ends" ( $p$. 801). This description is consistent with the definition proposed by Shaffer and Anundsen (1993), who defined a community as a dynamic whole that emerges when a group of people share common practices, are interdependent, make decisions jointly, identify themselves with something larger than the sum of their individual relationships, and make long-term commitments to the general group's well-being. Teacher development within professional communities highlights "working together in communities, both new and more experienced teachers pose problems, identify discrepancies between theories and practices, challenge common routines, draw on the work of others for generative frameworks, and attempt to make visible much of that which is taken for granted about teaching and learning" (Cochran-Smith \& Lytle, 1999, p.53). As a result, knowledge, skills and practices, developed within a professional community of inquiring teachers, are associated with improvements in student learning (Joyce \& Showers, 2002).

\section{Teacher Social Capital}

Harris and Anthony (2001) suggest that a central theme underlying many attempts to promote teacher development has been the notion that collegiality and collaboration contribute to teacher growth. As Leana (2010) writes, "When a teacher needs information or advice about how to do her job more effectively, she goes to other teachers. She turns far less frequently to the experts and is even less likely to talk to her principal (p.19)." Research shows that the teacher-learning community needs to provide an environment for long-term collaboration with colleagues, focusing on teaching content and issues related to the day-to-day practice of teaching (Cochran-Smith \& Lytle, 1999; Darling-Hammond \& Sykes, 1999). INSPIRE's practice of initially working with one cohort of teachers who will then assume the responsibility of supporting a new group of colleagues is designed to support the scaling up of the program interventions.

Teacher social capital consists of a set of social interaction assets such as collegiality, cooperation, collaboration, and reciprocity that enable teachers to work with each other in groups [1]. Scott (2000) classified teacher interaction as "relational data" which are mutual contacts, ties, and connections that cannot be reduced to the properties of the individual teachers themselves. Rather than focusing on teachers' attitudes, opinions, and 
behavior, which could be analyzed using variable analysis, methods related to relational data are called social network analyses.

Teacher social capital in a learning community can impact both teacher and student learning, resulting in instructional improvement and success in school reform (Little, 2002; Louis \& Marks, 1998). Goddard, Goddard, and Tschannen-Moran (2007) also found evidence that schools with greater levels of teacher interaction showed gains in student achievement. However, few studies address the impact of teacher professional development programs on student learning in elementary engineering education. There is a gap concerning effective interventions in elementary engineering education teacher professional development and the impact they have on student learning. Therefore, it is important to document teacher social capital and the impact of teacher-level factors on student learning achievement in an effort to provide indicators of methods for effective teacher professional development programs in elementary engineering education and broader K-12 engineering education.

\section{Purpose}

The purpose of this study is to examine the program's impact on student-learning achievement related to science and engineering design knowledge. If the students significantly increase their engineering design knowledge, the study further explores the extent to which differences among teachers affect student achievement. Seven variables at the teacher level are investigated to identity the key predictors for student achievement. Specifically, the questions being examined for this teacher professional development program are:

Q1: What is the impact of this teacher professional development program on student learning outcomes related to science and engineering design knowledge?

Q2: Do students' engineering design learning outcomes vary significantly across teachers? Part1: If true, to what extent do differences among teachers affect student achievement? Part2: If true, what are the teacher-level key factors?

\section{Method}

\section{Research Design}

A quantitative method is used to investigate the effectiveness of the program and key factors at the teacher level for student learning. A paired t-test was conducted to assess the first research question - the impact of this teacher professional development program on student learning outcomes in terms of science and engineering design knowledge. A two-level multilevel modeling analysis in which students were the level-1 units and teachers were the level-2 units was conducted to address the second research question. There were seven teacher factors; these are described in the data analysis section.

\section{Participants}

Three cohorts for a total of 90 teachers, from 15 elementary schools in this large school district, attended INSPIRE's teaching professional development program by the summer of 2010. For the social network analysis, all the teachers involved in the INSPIRE engineering education teacher professional development program were selected.

The students' data were collected under the condition that INSPIRE was in possession of teachers' consent forms, students' assent forms, and their parents' consent forms. To help the Spanish-speaking parents understand the purpose of this program, INSPIRE researchers also made the parents' consent forms available in Spanish. Teacher IDs, school IDs, and student IDs were used in the data analysis and the results report to ensure confidentiality for both the teachers and students.

In the 2009-10 school year, a total of 621 students in grades two through four (Kids age 7-10) participated in this study. Demographic information for grades two, three, and four students in the sample are provided in Table 1 . 
Table 1. Student Demographic Information

\begin{tabular}{cccccccccc}
\hline Grade & \multicolumn{4}{c}{ Ethnicity } & \multicolumn{3}{c}{ Gender } & \multicolumn{2}{c}{ Title I } \\
& White & Hispanic & $\begin{array}{c}\text { African } \\
\text { American }\end{array}$ & $\begin{array}{c}\text { Asian/Pacif } \\
\text { ic Indian/ }\end{array}$ & Male & Female & Non- & Tlaskan \\
Title I & & \\
\hline 2 & 54 & 54 & 32 & 24 & 2 & 91 & 79 & 114 & 76 \\
3 & 54 & 65 & 35 & 21 & 4 & 85 & 94 & 114 & 94 \\
4 & 85 & 72 & 28 & 19 & 2 & 122 & 95 & 118 & 105 \\
\hline
\end{tabular}

Title I: Eligible for federal funds.

\section{Data Sources}

\section{Social Network Survey}

A social network survey was administered to the teachers via the internet to gather self-reported teacher social capital data. Using scaled options, each respondent reported how he/she interacted with every other teacher in the network in regard to engineering topics. Participants received a roster with all INSPIRE teachers listed by schools in the community in rows and the interaction level in columns. This bounded method, namely the whole network study assessing relationships between individuals as bounded or closed, is a preferable social network strategy that provides a more complete picture of the network and thus supports valid results (Scott, 2000). The survey allowed for the following options: $1=\mathrm{I}$ don't know this teacher; $2=$ We have talked/communicated, but not about engineering; 3=We have talked/communicated briefly about engineering; 4=We have talked/communicated in some depth about teaching engineering; 5=We have prepared and/or collaborated related to teaching engineering; or Null: That's me! (The teacher who filled out the survey would be identified as Null)

The response rate reached $74 \%(\mathrm{~N}=90)$. As for non-respondents, however, the survey asks actors to name peers with whom they interact, thus allowing the non-response effect to be balanced out by reciprocal nominations (Stork \& Richards, 1992). According to Kossinets (2006), the non-response effect should be small, if not negligible, for response rates higher than $70 \%$.

\section{Students Pre-Post Knowledge Test}

The pre-test was administered to the students before the engineering instruction took place in their classes. The post-test, with questions in different sequences, was administered after all engineering instruction was complete. The students' knowledge test contained a total of fifteen questions for each grade level. The tests were composed of developmentally appropriate multiple-choice items that probe for different levels of comprehension. The test was organized into two main domains of knowledge: science related content knowledge (6-7 test items) and engineering design process and the work of an engineer (6-7 test items). Test items were generated by members of the research team, which included STEM faculty, research assistants, and elementary educators. The reliability of measurements obtained with the scale was $(\alpha=0.87)$ for the second grade knowledge test, $(\alpha=0.69)$ for the third grade knowledge test, and $(\alpha=0.73)$ for the fourth grade knowledge test (Dyehouse, Diefes-Dux \& Capobianco, 2011).

\section{Data Analysis}

Paired t-Test

A paired t-test was conducted to test the impact of the teacher professional development program on student achievement. The tests were graded and recorded at the item level. The scores for the two domains of knowledge (science and engineering design process) were used as dependent variables.

\section{Multilevel Modeling Analysis}

A two-level MLM analysis in which students were the level-1 units and teachers were the level-2 units was conducted using SAS software. To partition out the variance at different levels, we used the two-stage approach 
of multi-level modeling analysis, isolating the attributable amount of variance between teachers and within teachers. In the first stage, the analysis produced the "unconditional" model with no independent variables at the student and the teacher levels. At the first stage of the analysis, results from the following basic model (Model 1) were used to determine how much of the variation in students' knowledge gain originated at the student level or within-teacher, and how much originated at the teacher level or between-teachers.

$$
\begin{gathered}
\text { Unconditional Model (Model 1) } \\
\text { Level-1 (Student-level) } \\
\mathrm{Y}_{\mathrm{ij}}(\text { Student achievement })=\beta_{0 \mathrm{j}}+\mathrm{r}_{\mathrm{ij}}
\end{gathered}
$$

Where, $i$ is a subscript for an individual student and $j$ for the teacher. $\mathrm{Y}_{\mathrm{ij}}$ represents the knowledge test score of the student $i$ in the teacher $j$ class. $\beta_{0 \mathrm{j}}$ is the function of average knowledge score and the teacher-level variance for the students in teacher $j$ class. The error variance at the student level is represented by $\mathrm{r}_{\mathrm{ij}}$.

$$
\begin{gathered}
\text { Level-2 (Teacher-level) } \\
\beta_{0 \mathrm{j}}=\gamma_{00}++\mu_{0 \mathrm{j}}
\end{gathered}
$$

Where, $\gamma_{00}$ is the intercept or the grand mean of the dependent variable (i.e., knowledge score) for all teachers. $\mu_{0 \mathrm{j}}$ is the error variance at the teacher level. The statistics of interest in this stage are the variance components. The sum of level-1 and level-2 variances provides the total variance. The proportion of level-1 and level-2 variances is then computed to obtain the proportion of within-teacher and between-teacher variances. The proportion of the total variance that is between teachers is called the intra-class correlation (ICC), which, in other words, is the proportion of the total variance that can be explained by differences among teachers.

In the second stage, a succeeding model with additional predictors was assessed in comparison to the baseline, unconditional model. Seven teacher-level variables were introduced in the teacher-level equation to examine the relations between student knowledge achievement and the selected teacher-level variables. Following are the descriptions of the seven teacher-level factors:

Years of teaching: Number of years as a teacher $[0=$ less than 2 years, $1=3-5$ years, $2=6-10$ years, $3=$ over 11 years].

Master degree or below: The highest level of formal education completely by the teacher $[0=$ Do not have master's or doctoral degree, 1= Have master's or doctoral degree].

Gender: Gender of teachers is a dichotomous variable [ $1=$ Female, $0=$ Male $]$.

Title I: Eligible for federal funds. The school type in which the teacher is from $[1=$ Title I, $0=$ non Title I].

Cohort: The cohort the teacher is from [ $0=$ Cohort $1,1=$ Cohort 2]

Normalized degree: The teacher's social capital calculated as normalized centrality degree (continuous variable) using UCINET software. The degree is determined by the count of the number of ties to other actors in the network and can vary on a scale of 0 (the teacher has no relationship and occupies a marginal position in the social network) to 100 (the teacher initiates all the ties and occupies a central position in the network).

Betweenness: The teacher's social capital calculated as betweenness centrality degree (continuous variable) using UCINET. This refers to the extent to which a node lies between other nodes in the network. This measure calculates the length of the chains that connect a person to the totality of the network. It reflects the number of teachers to whom a teacher is connecting indirectly through their direct links. The higher the value, the more social capital the teacher has.

The conditional model was run using SAS. The results were used to determine the relationships between teacher-level variables and student achievement. Among which, the study tested whether teacher social capital was a key predictor for student achievement.

$$
\begin{gathered}
\text { Conditional Model (Model 2) } \\
\text { Level-1 }(\text { Student-level }) \\
\mathrm{Y}_{\mathrm{ij}}=\beta_{0 \mathrm{j}}+\mathrm{r}_{\mathrm{ij}} \\
\beta_{0 \mathrm{j}}=\gamma_{00}++\gamma_{01}(\text { Years of teaching })_{\mathrm{j}+} \gamma_{02}(\text { Master degree or below })_{\mathrm{j}+} \gamma_{03}(\text { Gender })_{\mathrm{j}+} \gamma_{04}(\text { Title I })_{\mathrm{j}+} \gamma_{05}(\text { Cohort })_{\mathrm{j}+} \\
\gamma_{06}(\text { (normalized degree })_{\mathrm{j}+} \gamma_{07}(\text { (betweenness })_{\mathrm{j}+} \mu_{0 \mathrm{j}}
\end{gathered}
$$


Where,

$\mathrm{Y}_{\mathrm{ij}}=$ the achievement of the student $i$ in the teacher $j$ class.

$\beta_{0 j}=$ the level-1 intercept of the regression equation predicting engineering design achievement at the end of the study in the $\mathrm{j}^{\text {th }}$ teacher's class

$\gamma_{00}=$ the intercept or the grand mean of the dependent variable (i.e., engineering design knowledge score) for all teachers in grade two

$\gamma_{00} \gamma_{07}=$ the coefficient of each teacher-level variable

$\mu_{0 j}=$ the error variance at the teacher level

$\mathrm{r}_{\mathrm{ij}}=$ the error variance at the student level

\section{Results}

Q1: What is the impact of this cyber-enabled teacher professional development program on student learning outcomes of science and engineering design knowledge?

The research question was examined using a paired t-test. The created variables of student science and engineering design test score were used as the dependent variables in the study. The variables are described as pre- to post-test change by grade level in Table 2.

Table 2. Student Assessment Pre- to Post-test Score Change for Grade 2 ( $\mathrm{n}=190)$, Grade 3 ( $\mathrm{n}=208$ ), and Grade

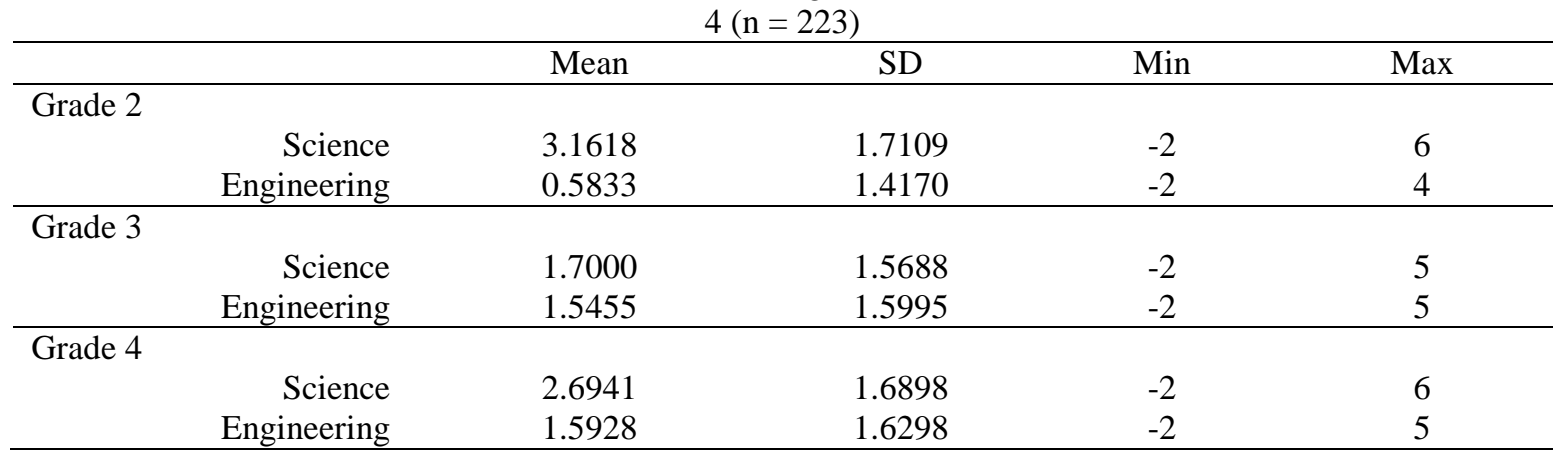

A two-tailed paired t-test indicated a significant increase in grade two students' knowledge in science from preto post-test $(\mathrm{df}=189 ; \mathrm{t}=37.33 ; \mathrm{p}<.0001)$, as well as in engineering design $(\mathrm{t}=8.32 ; \mathrm{p}<.0001)$. Similarly, a significant increase occurred in grade three students' science knowledge from pre- to post-test $(\mathrm{df}=207 ; \mathrm{t}=$ 22.73; $\mathrm{p}<.0001)$, as well as their engineering design knowledge $(\mathrm{t}=20.27 ; \mathrm{p}<.0001)$. As for grade four students, the results showed the same learning growth, a significant increase in science knowledge from pre- to post-test $(\mathrm{df}=220 ; \mathrm{t}=36.27 ; \mathrm{p}<.0001)$, as well as engineering design knowledge $(\mathrm{t}=23.40 ; \mathrm{p}<.0001)$.

The findings demonstrated that engaging in the integrated engineering design curriculum increased students' science and engineering design achievement. Significant increases occurred in students' science and engineering design knowledge $(\mathrm{p}<.001)$ across grades two, three, and four. Overall, the INSPIRE teacher professional development program had a significant impact on student achievement in science and engineering design. For the above paired-t tests, the study examined the data normality as well. The assumption of using paired-t tests is that data are normally distributed. To examine the normality assumption, a histogram and a Q-Q plot were created and showed no obvious deviations from normality. The assumption of normality was not violated for grades two, three and four.

Figure 1 and 2 were examples of the histogram and Q-Q plot for grade four students' achievement data normality check. 


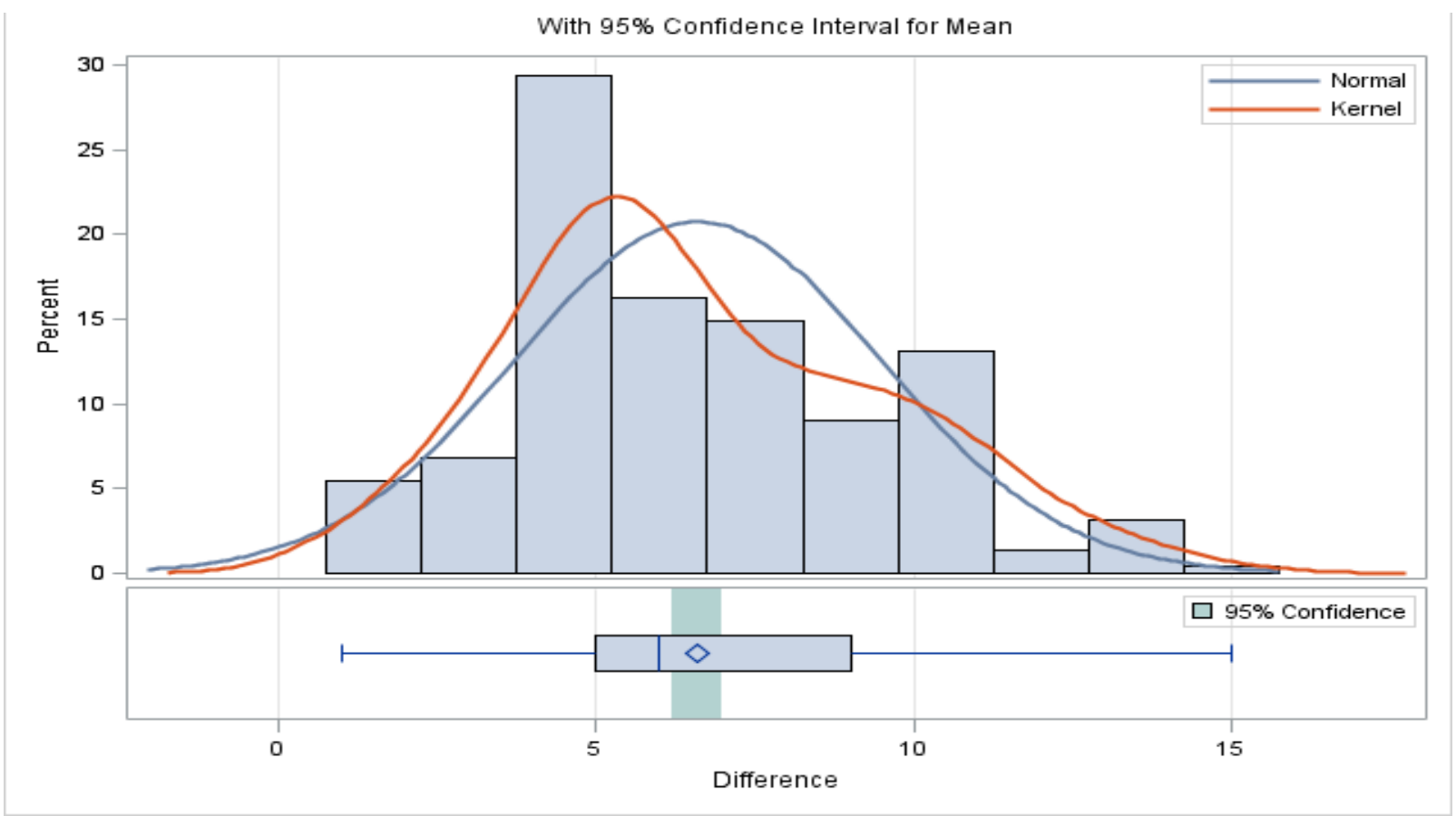

Figure 1. Grade 4 Distribution of Post- to Pre-test Difference with 95\% Confidence Interval for Mean

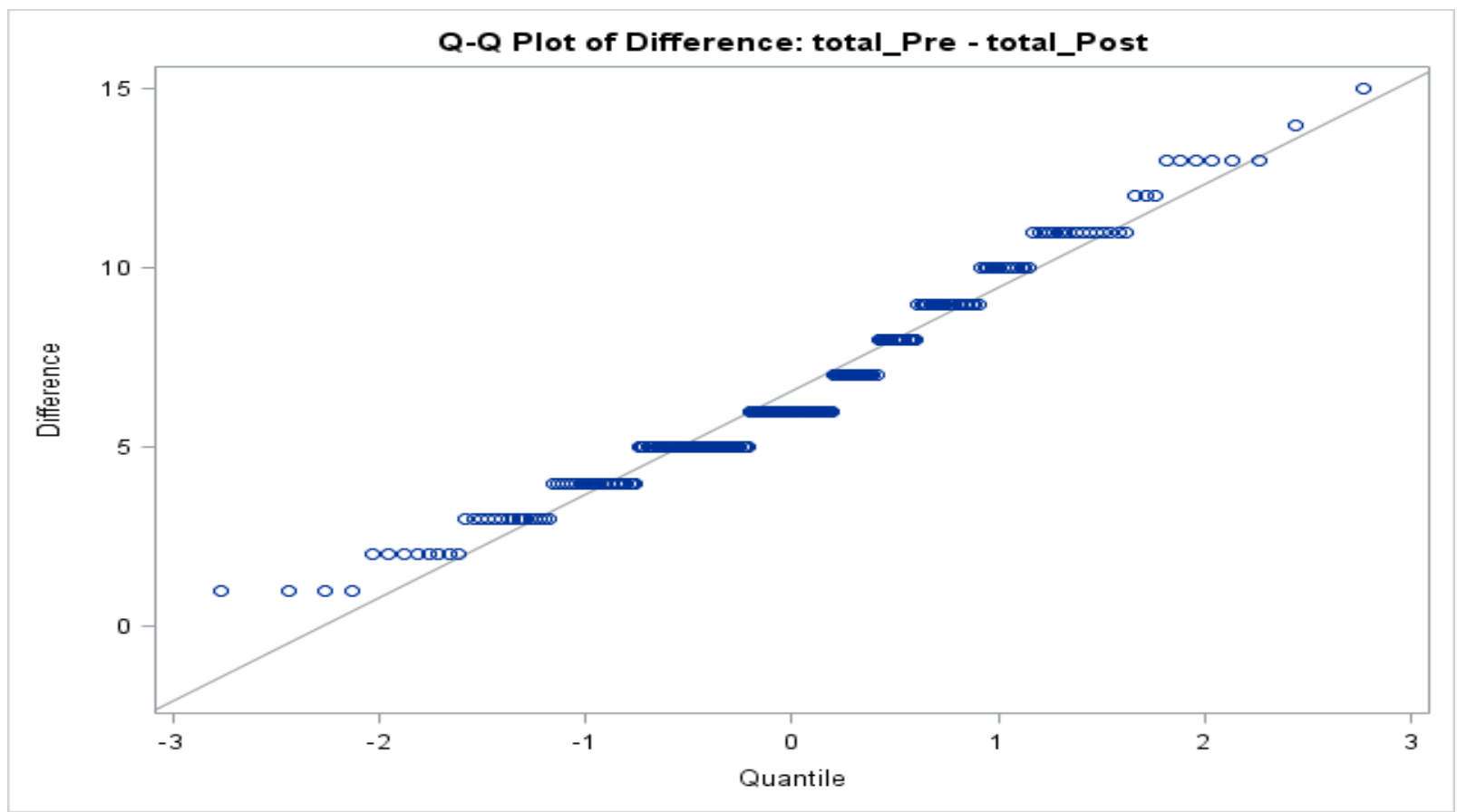

Figure 2. Grade 4 QQ Plot of Post- to Pre-test Difference

Q2: Do students' engineering design learning outcomes vary significantly across teachers? Part1: If true, to what extent do differences among teachers affect student achievement?

We start with variance-components model (unconditional mode) in grades two on engineering design. In the model as shown below in Table 3, the estimated value of $\tau_{00}=0.1629$ and the estimated value of $\sigma^{2}=2.5182$. Statistical testing in this section showed that both variance components are significantly different from zero, indicating that the difference among teachers did significantly impact their student engineering design achievement. However, there is much more variation among students within teacher/class since the variance component within classes $\left(\sigma^{2}\right)$ is 15 times the size of the variance component between teachers $\left(\tau_{00}\right)$. 
Similarly, the intra-class correlation was calculated, which indicates what portion of the total variance of student achievement was due to between teachers/classes. The intra-class correlation (ICC) formula is as follows:

$$
P(I C C)=\tau_{00} /\left(\tau_{00}+\sigma^{2}\right)
$$

An ICC of .06 indicates that $6 \%$ of the engineering design achievement gain in grade two was explained by differences among teachers.

Table 3. Grade 2 Engineering Design Fixed and Random Effects for the 2-level Unconditional Model

\begin{tabular}{lllll}
\multicolumn{3}{c}{$(\mathrm{ICC}=0.06)$} & \\
\hline Fixed Effects & Coefficients & $\mathrm{SE}$ & t-ratio & $p$ \\
Intercept $\gamma_{00}$ & 2.0659 & 0.1288 & 16.04 & $<.0001$ \\
\hline Random Effects & Variance components & $\mathrm{SE}$ & z-ratio & $p$ \\
Intercept $\tau_{00}$ & 0.1629 & 0.09794 & 1.66 & $<.05$ \\
Residual $\sigma^{2}$ & 2.5182 & 0.1799 & 14.00 & $<.0001$ \\
\hline
\end{tabular}

Model Fit

\begin{tabular}{lr} 
AIC & 1555.3 \\
BIC & 1556.9 \\
\hline
\end{tabular}

$\mathrm{ICC}=0.06$

The engineering design achievement gain in Grade 3 was explained more by differences among teachers than in Grade 2, as the ICC is $15 \%$ (see Table 4).

Table 4. Grade 3 Engineering Design Fixed and Random Effects for the 2-level Unconditional Model

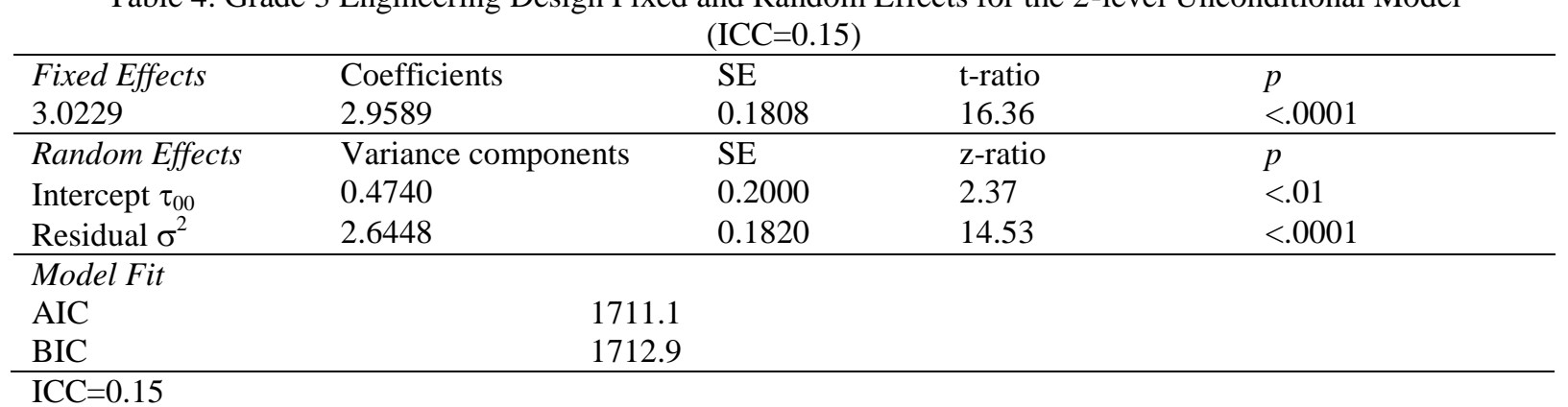

As for grade 4, $10 \%$ of the engineering design achievement gain was explained by differences among teachers (see Table 5). The data normality was also checked using residual plot. For example, Figure 3 shows residuals for engineering design knowledge achievement in Grade 4.

Table 5. Grade 4 Engineering Design Fixed and Random Effects for the 2-level Unconditional Model

\begin{tabular}{lllll}
\multicolumn{3}{c}{$(\mathrm{ICC}=0.10)$} & \\
\hline Fixed Effects & Coefficients & $\mathrm{SE}$ & t-ratio & $p$ \\
Intercept $\gamma_{00}$ & 3.0229 & 0.1629 & 18.56 & $<.0001$ \\
\hline Random Effects & Variance components & $\mathrm{SE}$ & z-ratio & $p$ \\
Intercept $\tau_{00}$ & 0.3349 & 0.1639 & 2.04 & $<.05$ \\
Residual $\sigma^{2}$ & 2.9382 & 0.1945 & 15.10 & $<.0001$ \\
\hline
\end{tabular}

Model Fit

$\begin{array}{ll}\text { AIC } & 1884.5 \\ \text { BIC } & 1886.2\end{array}$

$\mathrm{ICC}=0.10$ 

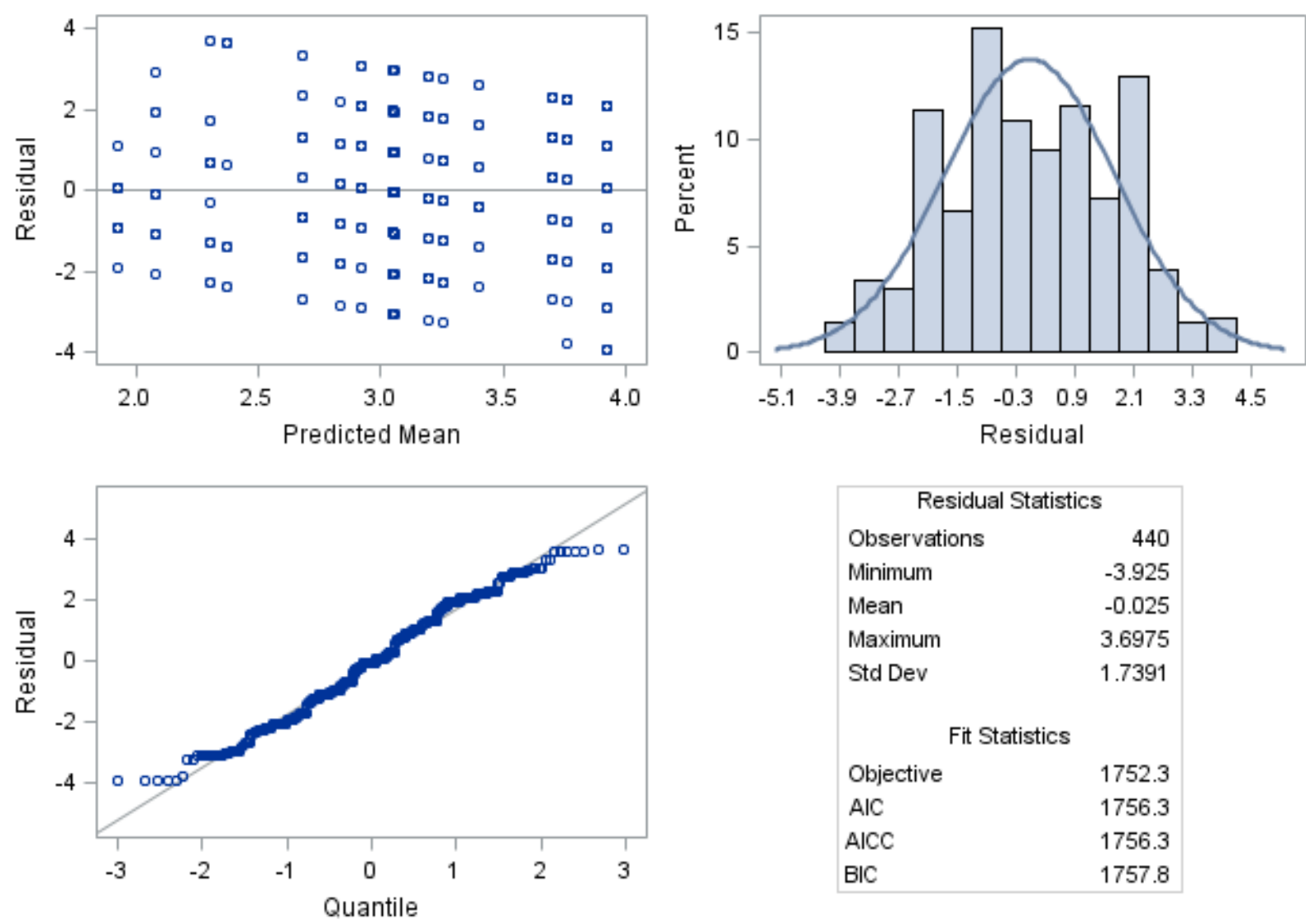

\begin{tabular}{|lr|}
\hline \multicolumn{2}{|c|}{ Residual Statistics } \\
Observations & 440 \\
Minimum r & -3.925 \\
Mean & -0.025 \\
Maximum & 3.6975 \\
Std Dev re & 1.7391 \\
& \\
\multicolumn{1}{|c|}{ Fit Statistics } \\
Objective & 1752.3 \\
AIC & 1756.3 \\
AICC & 1756.3 \\
BIC & 1757.8 \\
\hline
\end{tabular}

Figure 3. Residuals for Engineering Design Knowledge Achievement in Grade 4

One of the most discussed and debated elements that is related to teacher effectiveness is the amount of value a teacher adds to the achievement of his or her students (Daly, Moolenaar, Der-Martirosian, \& Chrispeels, 2010). While teachers return from professional development training to their classes, they have influence on their students, "few do damage, some maintain a status quo in growth of student achievement, and many are excellent" (Hattie, 2003, p.15). Teacher professional development programs intend to train all teachers to be equally effective at teaching in their classes. This study used multilevel modeling to empirically determine how much of the variation in students' knowledge gain originated at the student or within-teacher levels, and how much originated at the teacher level or between-teachers in the INSPIRE program.

The results of this study showed that differences among teachers were consistently related to student achievement in engineering design knowledge across investigations of grade two, three, and four classes. The differences among teachers explained most of student engineering design knowledge in grade three, which is $15 \%$. It means that teaching effectiveness for grade three varied most across teachers. One reason might be the effort teachers in each grade level put toward integrating engineering into the class.

In the first year implementation of this program, INSPIRE researchers Yoon, Diefes-Dux, and Strobel (2012) found that third grade teachers spent significantly more time delivering engineering integrated curriculum than fourth grade teachers. The more time teachers spent on teaching the unit, the more likely differences among teachers played an important role in student learning. Another reason could be different levels of difficulty associated with the engineering units. In the program, each grade level adopted a different engineering area. Grade two was a "Play Dough" chemistry engineering unit. Grade three was a "Simple Machine" industrial engineering unit. Grade four was a "Plant Packaging" packaging engineering unit. Teachers might have experienced different levels of difficulty in teaching the units.

Last but not least, a major portion of the variance in student achievement was explained by differences among students themselves. This aligns with the common belief that the majority of variation in student achievement can be attributed to students themselves. Characteristics among individual students were more varied than the characteristics across teachers or classrooms. 
Q2: Do students' engineering design learning outcomes vary significantly across teachers? Part2: If true, what are the teacher-level key factors?

The students' engineering design learning outcomes varied significantly across teachers in all grades two, three, and four. So the seven teacher-level variables were used to investigate key predictors at the teacher level for student engineering design achievement. A MLM conditional model with all teacher-level variables was conducted. Take grade two student engineering design achievement for example. The factors of teacher year in cohort and educational background at the teacher-level were significant $(p<.05)$. On average, when teachers have a master's degree, their students achieved 0.58 points higher in engineering design achievement $(\mathrm{p}<.001)$ compared with teachers without a master's degree, while controlling for other variables. On the other hand, students achieved 0.70 points higher in engineering design achievement ( $p$ <.001) with teachers who attended the cohort one year earlier, when controlling for other variables.

As for grade three, there were two key predictors at the teacher level for student engineering design achievement: education background and teacher social capital of normalized degree. On average, students achieved 0.67 points higher $(\mathrm{p}<.05)$ in the classroom when the teacher has a master degree, controlling for other variables. With one point increase of teacher social capital normalized degree, students achieved 0.15 points higher $(\mathrm{p}<.01)$. As for grade four, there was only one key predictor at teacher level for the engineering design knowledge achievement: whether teachers taught in Title I schools (Title I schools are eligible for federal funds). On average, students achieved 0.88 points higher in engineering design achievement $(\mathrm{p}<.01)$ when teachers taught in non-Title I schools.

Multilevel modeling analyses found different predictive relationships between factors at the teacher level and student achievement across grades two, three, and four. In grade two, the year in cohort was significantly associated with student engineering design knowledge achievement. Teachers in Cohort 1 tended to have higher scores from their students compared with teachers in Cohort 2 who joined the INSPIRE program one year later. Yoon, Diefes-Dux, and Strobel (2012) revealed that the teachers significantly increased their engineering design knowledge during the first year INSPIRE program implementation from 2008-2009. Further, this study indicates that the INSPIRE teacher professional development program has accumulative effect on teachers' engineering design and teaching knowledge. The longer teachers stay in the program, the more likely they are to equip themselves with engineering design and teaching knowledge, thus increasing their students' chance of learning engineering design.

In both grades two and three, teacher educational background was significantly associated with student engineering design knowledge achievement. Teachers with a master's degree also positively predicted higher student engineering design achievement. Previous research shows that teachers with master's degrees are more likely to improve student achievement at the secondary level. For example, Clotfelter, Ladd, and Vigdor (2007) found that teachers who held master's degrees made greater student learning gains than teachers without advanced degrees. In this elementary teacher professional development program, it was found that teachers with advanced degrees (master's or above) improved the students engineering design knowledge more than those with bachelor's degrees or below.

In grade three, teacher social capital of normalized degree contributed significantly to student engineering design knowledge achievement in grade three. The normalized degree centrality is useful in assessing which nodes are central with respect to spreading information and influencing others in their immediate neighborhood. A teacher with more social capital will improve his or her students' learning achievement. The importance of social capital implies that it is well worth the time and effort to create an atmosphere of community in the teacher professional development program, where teacher collegiality and collaboration are developed and encouraged.

Certainly, people might think that, as long as teachers have a greater number of connections, they will benefit. However, this is not always the case. Another variable, betweenness degree, also matters. It is useful in determining points where the network would break apart. Therefore, as a cutpoint in the network connecting two other teachers, a between teacher might control the flow of information or the exchange of resources. In this study, teacher social capital marked by betweenness centrality degree was not a key predictor. This is not to say that betweenness is not important. Perhaps the finding was due to the well-connected network in which no teacher was totally cut off from the program. In other words, the study found no teacher to be a bottleneck. In grade four, school type was significantly associated with student engineering design knowledge achievement. Further studies are needed to investigate how schools utilize Title 1 status and Title 1 funds. Especially, the 
relationship between educational resources allocation, utilization, and student achievement needs to be further studied.

\section{Limitations and Future Research}

The study did not distinguish between the sources of social capital, which could come either from face-to-face interactions or from the cyber-enabled community. When it comes to the sociogram analyses, the results show the self-reported interactive relationships between and among teachers directly. It helps one to understand the teachers' relations and provides a whole picture to describe teacher-social capital. However, sociograms alone cannot fully explain what kind of meaning lies behind the lines. Even though the study used robust statistical techniques, it would benefit from a qualitative study. Triangulation of multiple resources, such as observations and follow-up interviews, will inform researchers and help them to understand the phenomenon.

As for multilevel modeling analysis, this study is also limited in that we have examined evidence from a relatively small number of teachers. Future studies with a larger number of teachers are desired. In an effort to explain different achievement levels in elementary science, engineering, and overall achievement among grades two, three and four, the selected teacher-level variables were not inclusive. There could be various other factors that might explain the achievement variances among the students. Although we did not discuss many statistical inferences, adaptations have been developed for use with network data, which provide a practical way to examine association of network parameters with student achievement outcomes in current practices.

\section{Conclusions}

The study is exploratory in nature and could not provide direct evidence required for determining causal effects. Yet, the results of the study might suggest educational resources allocation. One recommendation is to provide additional support for teachers without advanced degrees in the elementary engineering education programs. This recommendation is echoed by the program first year implementation study conducted by Yoon, DiefesDux, and Strobel (2013). Teachers' acquisition of engineering design knowledge significantly differed by their education level. Teachers with master's degrees or above increased knowledge more than ones with bachelor's degrees or below. When it comes to educational resources allocation, this supports school district actions to encourage and reward teachers' additional experience and degrees.

The flow of knowledge resources in elementary schools may be limited, given long-held traditions of teacher autonomy and isolation (Daly, Moolenaar, Der-Martirosian, \& Chrispeels, 2010). Policy makers have not devoted much attention to incentives and regulations that might foster teacher social capital within school settings. Reform efforts could have focused on providing opportunities for teacher collaboration and the creation of professional learning communities especially at the elementary level (Louis \& Marks, 1998; Stoll \& Louis, 2007). Some studies, including this study, have shown evidence that teacher social capital may have a significant effect on student achievement. As Pil and Leana (2009) discussed, "such findings suggest the potential effect of teacher social capital on student learning and, if confirmed, would have important implications for where public investment in schools might be most effectively made" (p.1102). Developing an atmosphere of collaboration takes an investment of time and effort but, as indicated by the empirical results, has a return in greater student achievement. School improvement requires social capital to be nurtured, enabling teachers to share and combine their learning and pedagogies to effectively formulate an active community of practice.

Overall, this teacher professional development program made a significant impact on students' science and engineering knowledge. The study presents empirical evidence of the impact of differences among teachers on the engineering design achievement of their students. Furthermore, the study identifies the key factors at the teacher level for student learning and therefore has implications for educational policymaking and practices.

\section{Acknowledgement}

This work was made possible by a grant from the National Science Foundation (DRL 0822261). Any opinions, findings, and conclusions or recommendations expressed in this material are those of the authors and do not necessarily reflect the views of the National Science Foundation. 


\section{References}

Anderson, J. B. (2008). Social capital and student learning: Empirical Results from Latin American Primary Schools. Economics of Education Review, 27, 439-449.

Brophy, S., Klein, S., Portsmore, M., \& Rogers. C. (2008). Advancing engineering education in the P-12 classrooms. Journal of Engineering Education, 97(3), 369-387.

Barab, S., Kling, R., \& Gray, J. (2004). Designing for virtual communities in the service of learning. New York: Cambridge University Press.

Carr, R. L., Bennett, L. D. \& Strobel, J. (2012). Engineering in the K-12 STEM standards of the 50 U.S. states: An analysis of presence and extent. Journal of Engineering Education, 101(3), 1-26.

Cochran-Smith, M., \& Lytle, S. L. (1999). Relationships of knowledge and practice: Teacher learning in communities. Review of Research in Education, 24, 249-305.

Daly, A. J., Moolenaar, N., Bolivar, J., \& Burke, P. (2010). Relationships in reform: The role of teachers' social networks. Journal of Educational Administration, 48(3), 20-49.

Darling-Hammond, L., \& Sykes, G. (Eds.). (1999). Teaching as the learning profession: Handbook of policy and practice. San Francisco: Jossey-Bass.

Diefes-Dux, H. A. (2014). In-service teacher professional development in engineering education: early years. In S. Purzer, J. Strobel, \& M. E. Cardella (Eds.), Engineering in pre-college settings: synthesizing research, policy, and practices (pp. 233-257). West Lafayette, IN: Purdue University Press.

Diefes-Dux, H. A. (2015). Introducing engineering in elementary education: a five-year study of teachers and students. British Journal of Educational Technology, 46(5), 1015-1019. doi:10.1111/bjet.12319

Duncan, D., Oware, E., Cox, M.F., and Diefes-Dux, H. A. (2007). Program and curriculum assessment for the institute for P-12 engineering research and learning (INSPIRE) summer academies for P-6 teachers. Proceedings of the ASEE Annual Conference \& Exposition, Honolulu, HI.

Dyehouse, M., Diefes-Dux, H. A. \& Capobianco, B. (2011). Measuring the effects of integrating engineering into the elementary school curriculum on students' science and engineering design content knowledge. Proceedings of the 118th ASEE Annual Conference \& Exposition, Vancouver, BC, Canada.

Goddard, Y. L., Goddard, R. D., \& Tschannen-Moran, M. (2007). A theoretical and empirical investigation of teacher collaboration for school improvement and student achievement in public elementary schools. Teachers College Record, 109, 877-896.

Harris, D.L. \& Anthony, H.M. (2001). Collegiality and its role in teacher development: Perspectives from veteran and novice teachers. Teacher Development, 5(3), 371-390.

Hattie, J. (2003). Teachers make a difference: What is the research evidence? Keynote presentation at the Building Teacher Quality: The ACER Annual Conference, Melbourne, Australia.

Strobel, J. \& Liu, W. (2010). How to run a video embedded classroom study: Practices of INSPIRE. Proceedings of Society for Information Technology \& Teacher Education International Conference, (pp. 1199-1202), San Diego, CA.

Jonassen, D.H. (2000). Toward a design theory of problem solving. Educational Technology: Research \& Development, 48(4), 63-85.

Joyce, B., \& Showers, B. (2002). Student achievement through staff development (3rd ed.). Alexandria, VA: Association for Supervision and Curriculum Development.

Kossinets, G. (2006). Effects of missing data in social networks. Social networks, 28, 247-268.

Leana, C. M. (2010). Social capital: The collective component of teaching quality. In Collective Practice Quality Teaching (pp. 16-23). Retrieved July 15, 2011, from www.annenberginstitute.org

Little, J. W. (2002). Locating learning in teachers' communities of practice: opening up problems of analysis in records of everyday work. Teaching and Teacher Education, 18, 917-946.

Louis, K. S., \& Marks, H. M. (1998). Does professional community affect the classroom? Teachers' work and student experiences in restructuring schools. American Journal of Education, 106(4), 532-575.

Liu, W., Carr, R., \& Strobel, J. (2009). Extending teacher professional development through an online learning community: A case study. Journal of Educational Technology Development and Exchange, 2(1), 99-112.

Liu W., Carr R.L., Strobel J. (2012) Needs Assessment: Developing an Effective Online P-6 Engineering Professional Development Program. In: Moller L., Huett J. (eds) The Next Generation of Distance Education. Springer, Boston, MA.

National Academy of Engineering (NAE). (2008). Changing the conversation: Messages for improving public understanding of engineering. Washington, DC: The National Academies Press.

Next Generation Science Standards (USA, 2014). http://www.nextgenscience.org.

Pil, F. K., \& Leana, C. (2009). Applying organizational research o public school reform: The effects of teacher human and social capital on student performance. Academy of Management Journal, 52(6), 1101-1124. 
Schlager, M. S. \& Fusco, J. (2004). Teacher professional development, technology, and communities of practice: Are we putting the cart before the horse? In S. Barab, R Kling, \& J. Gray (Eds.), Designing virtual communities in the service of learning. Cambridge University Press.

Shaffer, C. R., \& Anundsen, K. (1993). Creating community anywhere: Finding support and connection in a fragmented world. New York: Putnam.

Scott, J. (2000). Social network analysis: A handbook (2nd ed.). Thousand Oaks, CA: Sage.

Stoll, L. \& Louis, K. (2007). Professional learning communities. Open University Press, Milton Keynes, UK.

Stork, D., \& Richards, W. D. (1992). Nonrespondents in communication network studies: Problems and possibilities. Group \& Organization Management, 17(2), 193-209.

Sun, Y., \& Strobel, J. (2014). From knowing-about to knowing-to: Development of engineering pedagogical content knowledge by elementary teachers through perceived learning and implementing difficulties. American Journal of Engineering Education, 5(1), 41-60.

Yoon, S. Y., Diefes-Dux, H., \& Strobel, J. (2013). First-year effects of an engineering professional development program on elementary teachers. American Journal of Engineering Education, 4(1), 67-84.

Sun, Y., \& Strobel, J. (2014). From knowing-about to knowing-to: Development of engineering pedagogical content knowledge by elementary teachers through perceived learning and implementing difficulties. American Journal of Engineering Education, 5(1), 41-60.

Wenger, E. (1998). Communities of practice: Learning, meaning, and identity. Cambridge, UK: Cambridge University Press.

Wilson, B., \& Ryder, M. (1996). Dynamic learning communities: An alternative to designed instructional systems. Proceedings of National Convention of the Association for Educational Communications and Technology (pp. 800-809), 1997, AECT, Indianapolis, IN.

Yoon, S. Y., Diefes-Dux, H., \& Strobel, J. (2013). First-year effects of an engineering professional development program on elementary teachers. American Journal of Engineering Education, 4(1), 67-84.

\begin{tabular}{lc}
\hline & Author Information \\
\hline Wei Zakharov & Johannes Strobel \\
Purdue University & University of Missouri, Columbia \\
3053 WALC, 340 Centennial Mall Drive & 221B Townsend Hall \\
West Lafayette, IN 47907 & Columbia, MO 65211 \\
USA & USA \\
Contact e-mail: wzakharov@purdue.edu & \\
Heidi A. Diefes-Dux & \\
University of Nebraska-Lincoln & \\
251 Chase Hall & \\
Lincoln, NE 68583 & \\
USA & \\
\hline
\end{tabular}

